Wiesława KOPIEJEWSKA, Małgorzata JANKUN, Ilona MROWIŃSKA

Ichthyobiology

\title{
FECUNDITY AND RESERVE OF THE OOCYTES OF PROTOPLASMATIC GROWTH IN THE OVARIES OF BREAM, ABRAMIS BRAMA (L.), FEMALES IN TWO KONIN LAKES
}

\section{PŁODNOŚĆ I ZAPAS OOCYTÓW PROTOPLAZMATYCZNEGO WZROSTU W JAJNIKACH SAMIC LESZCZA, ABRAMIS BRAMA (L.), W DWÓCH ZBIORNIKACH JEZIOR KONIŃSKICH}

Chair of Zoology, Chair of Basic Fishery Sciences, University of Agriculture and Technology, Olestyn

Lakes Gosławskie and Ślesińskie are two out of five Konin lakes which receive a discharge of heated effluents from "Pątnow" and "Konin" power plants. In these two lakes bream females are characterized by single portion spawning. $25 \%$ of the females tend to batch spawning. Lake Gosławskie is warmer than Lake Slesinskie: in about $46 \%$ of bream females from this lake percentage of maturing oocytes in the ovaries was higher than in Lake Slesinskie (and than in natural conditions), 20-38.8\%. Increased temperature in Lake Slesinskie caused intensive development of eggs in the ovaries of young females, 3-7 years old, so that they passed from the class of modertly growing to the class of rapidly growing. In Lake Gostawskie maturation of eggs in the ovaries of 4-6 year old females became even more intensive, so that they passed from the class of slowly growing to the class of more than moderately or rapidly growing ones.

\section{INTRODUCTION}

Thermal pollution of lakes results in many changes in the natural conditions (Hillbricht-Ilkowska and Zdanowski 1988 a, b and others). As regards fish repro- 


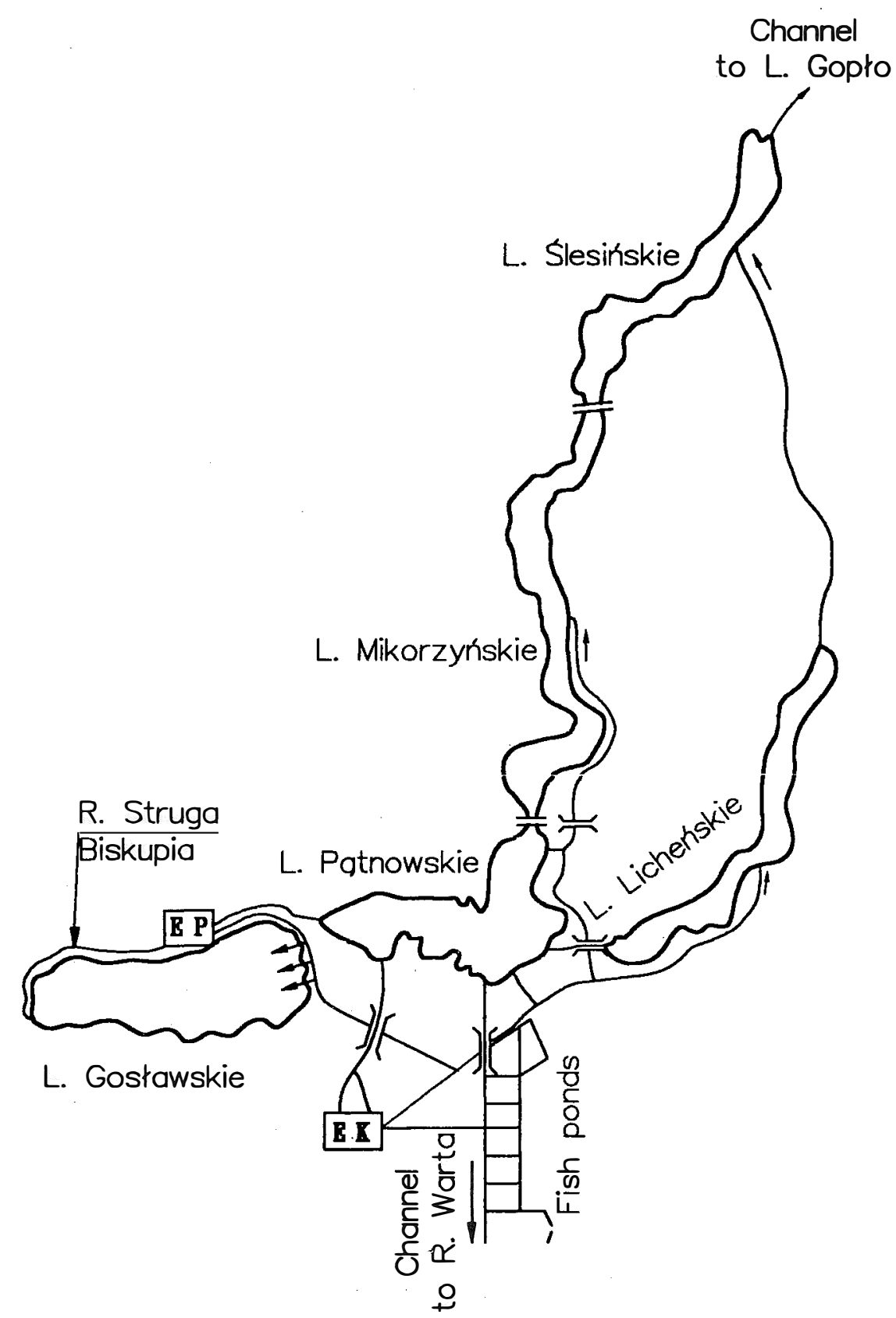

Fig. 1. Schema of the cooling system of "Konin" (EK) and "Patnow" (EP) power plants (according to Hillbricht-Ilkowska, Zdanowski 1988 a) 
duction in such water bodies, processes related to maturation of the egg cells in the ovaries become intensified, and the same is true of the resorption of these cells. It was found that:

- sexual maturity was attained earlier,

- oocyte vitellogenesis became shorter and the fish spawned earlier (Kokurewicz 1979, Lukshene 1983, Długosz 1986, Wilkońska 1988 a),

- spawning period prolonged (Wilkońska and Żuromska 1977 a, Kokurewicz 1979, Długosz 1986),

- post-spawning stage of the ovaries and oocyte vacuolization phase were longer (Lukshene 1983, Długosz 1986),

- in the case of batch spawning the time interval between consecutive egg batches became shorter (Lukshene 1983),

- in the case of single portion spawning the oocyte development in the ovaries was asynchronic (Statova 1973, Efimova 1977, Lukshene 1983, Długosz 1986),

- some fish did not spawn or laid only part of mature oocytes, so that resorption of mature oocytes took place in the ovaries (Lukshene 1983, Długosz 1986).

Konin lakes have been included into the cooling system of "Konin" and "Pątnów" power plants succesively since 1958 (Zdanowski and Korycka 1976). Untill 1969 heated effluents from the first power plant "Konin" were discharged via a system of canals to Lake Licheńskie and south part of Lake Mikorzyńskie. Lake Pątnowskie received heated waters from Lake Mikorzyńskie becaus the two lakes are interconnected (Fig. 1). Ichthyobiological studies were carried out at that time. They delt with fish growth (Ciepielewski 1977, Marciak 1977, Wilkońska 1977, Żuromska 1977), changes in species composition of the fry (Wilkońska and Żuromska 1977 b), fry growth (Wilkońska and Żuromska 1977 c), fish reproduction (Wilkońska and Żuromska 1977 a). At the turn of 1969 and 1970 power plant "Pątnów" began to operate and Lake Slesińskie was connected by means of a canal with Lake Licheńskie. This way all Konin lakes were included into the cooling system (Fig. 1). After 1970 studies were made on the morphology and biology of chub (Jakubowski et al. 1979), roach growth (Chmielewski 1985), annual cycle of gonads in roach, perch, and pike-perch (Długosz 1983 a, b, c), meristic parameters in roach and perch Szczyglińska 1980), fry communities (Wilkońska 1989), changes in fry species composition (Wilkońska and Żuromska 1983 a), fry growth (Wilkońska and Żuromska 1983 b), fish responces to environment heating (Wilkońska 1988 a) and the effect of introducing phytophagous fish on the reproduction of local species in heated Lake Gosławskie (Wilkońska 1988 b).

This paper presents fecundity and proportion of oocytes in the ovaries of bream females from lakes Gosławskie and Ślesińskie. The aim of the study was to determine whether long-term heating induced changes in the functioning of bream ovaries with respect to the numbers of maturing eggs and the oocytes of protoplasmatic growth. 
MATERIAL, METHOD, ENVIRONMENT

Material consisted of 38 bream females collected on 12 Feb. 1986 from Lake Gosławskie and 73 females collected on 3 March 1986 from Lake Ślesińskie. Bream females from Lake Gosławskie were of body length (1.c.) 28.5-46.0 cm, and weight 640-2110 g, aged 4-7 years. Sample collected in Lake Ślesińskie was more differentiated: fish body length ranged from 21.0 to $48.0 \mathrm{~cm}$ (1.c.), weight from 200 to $2290 \mathrm{~g}$. These fish were aged 3-12 years.

Fecundity was determined with weight method for all 111 females. In addition to this 15 females from Lake Gosławskie and 15 from Lake Ślesińskie were used to

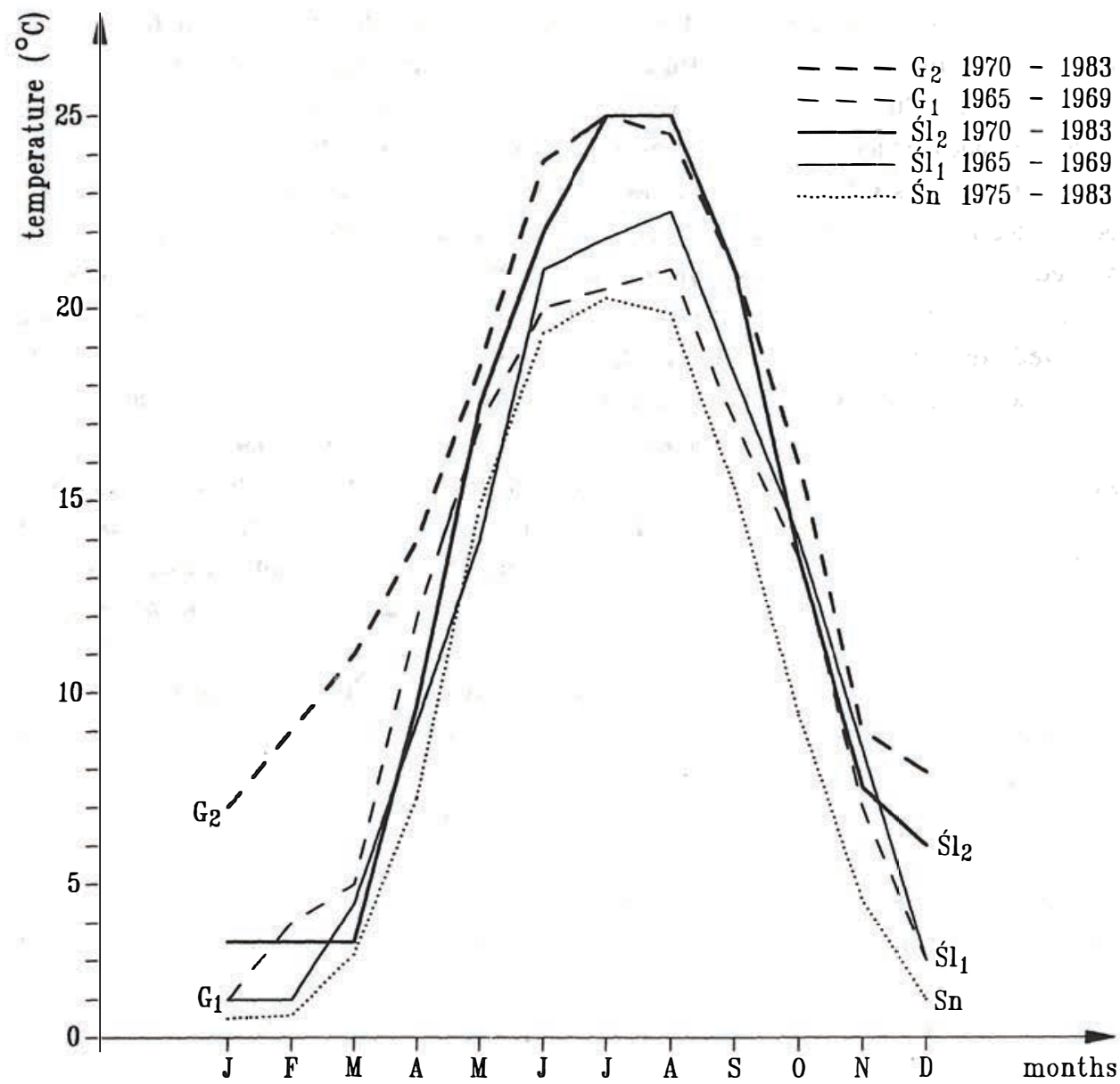

Fig. 2. Mean seasonal surface water temperature in lakes: Gosławskie (G), Ślesiñskie (Śl) in 1965-1969 and 1970-1983 (according to Hillbricht-Ilkowska, Zdanowski 1988 a), Śniardwy (Śn) in 1975-1983 (according to $\mathrm{IM}$ and $\mathrm{CW}$ ) 
take scraps of the ovaries in order to determine percentages of oocytes in the ovaries. Percentages of the oocytes of proto- and trophoplasmatic growth in the ovaries were determined counting the oocytes in the scraps. Sum of proto- and trophoplasmatic oocytes was taken as $100 \%$

Lakes: Gosławskie and Ślesińskie, two of five thermally polluted Konin lakes but to a different extent (Zdanowski and Korycka 1976, Hillbricht-Ilkowska and Zdanowski 1988 a). Heated effluents are discharged to Lake Gosławskie throughout the year, while Lake Ślesińskie receives only periodic discharge since May till November. Lake Gosławskie is shallow, polymictic, eutrophic, of pond type. Lake Ślesinnskie is a deep, finger lake, dimictic, eutrophic. Average monthly temperatures of surface water layers in the two lakes since 1965 till 1969 (1st period) and since 1970 till 1983 (2nd period), and average monthly temperatures in a natural Lake Śniardwy in 1975-1983 are presented in Fig. 2. Average montly temperatures of surface water in lakes Gosławskie and Ślesińskie in 1965-1969 were natural ones because in the 1st period these lakes were not thermally polluted. In 1973-1983 average monthly temperatures in water of Lake Gosławskie increased by $5-6^{\circ} \mathrm{C}$ in winter, $1.5-6^{\circ} \mathrm{C}$ in spring, $3.5-4.5^{\circ} \mathrm{C}$ in summer, and $2-4^{\circ} \mathrm{C}$ in autumn compared to the first period. In Lake Ślesińskie the differences were not so pronounced: $1.5-3^{\circ} \mathrm{C}$ in winter, $0.5-3^{\circ} \mathrm{C}$ in spring, $1-3.5^{\circ} \mathrm{C}$ in summer, and $2.5^{\circ} \mathrm{C}$ in autumn. In the period of heated effluent discharge (May-September) water temperature was higher by $1-3.5^{\circ} \mathrm{C}$.

\section{RESULTS}

Histological picture of the ovaries and proportion of oocytes in bream ovaries in lakes Gosławskie and Ślesińskie.

The degree of gonad development in bream females collected in February from Lake Gosławskie and in March from Lake Ślesińskie was determined as IV stage according to the scale by Sakun and Buckaja (1968) (Phot. 1). Oocytes of trophoplasmatic growth were totally or in $3 / 4$ filled with yolk. Their nuclei were centrally located. In the ovaries of about $25 \%$ of the females from Lake Gosławskie and about $26 \%$ in Lake Ślesińskie there were oocytes in the initial stage of vacuolization (Phot. 2). These oocytes had 1-2 rings of small vacuoles near the follicular envelope. They were counted as reserve oocytes (oocytes of protoplasmatic growth). Proportions of oocytes in the ovaries and individual characteristics of the females are presented in Tables 1 and 2. Bream females taken for histological examination from Lake Gosławskie were 4-7 years old, with body length $28.5-43.0 \mathrm{~cm}$ and body weight 640-1670 g. Bream females taken for histological examination from Lake Ślesińskie 


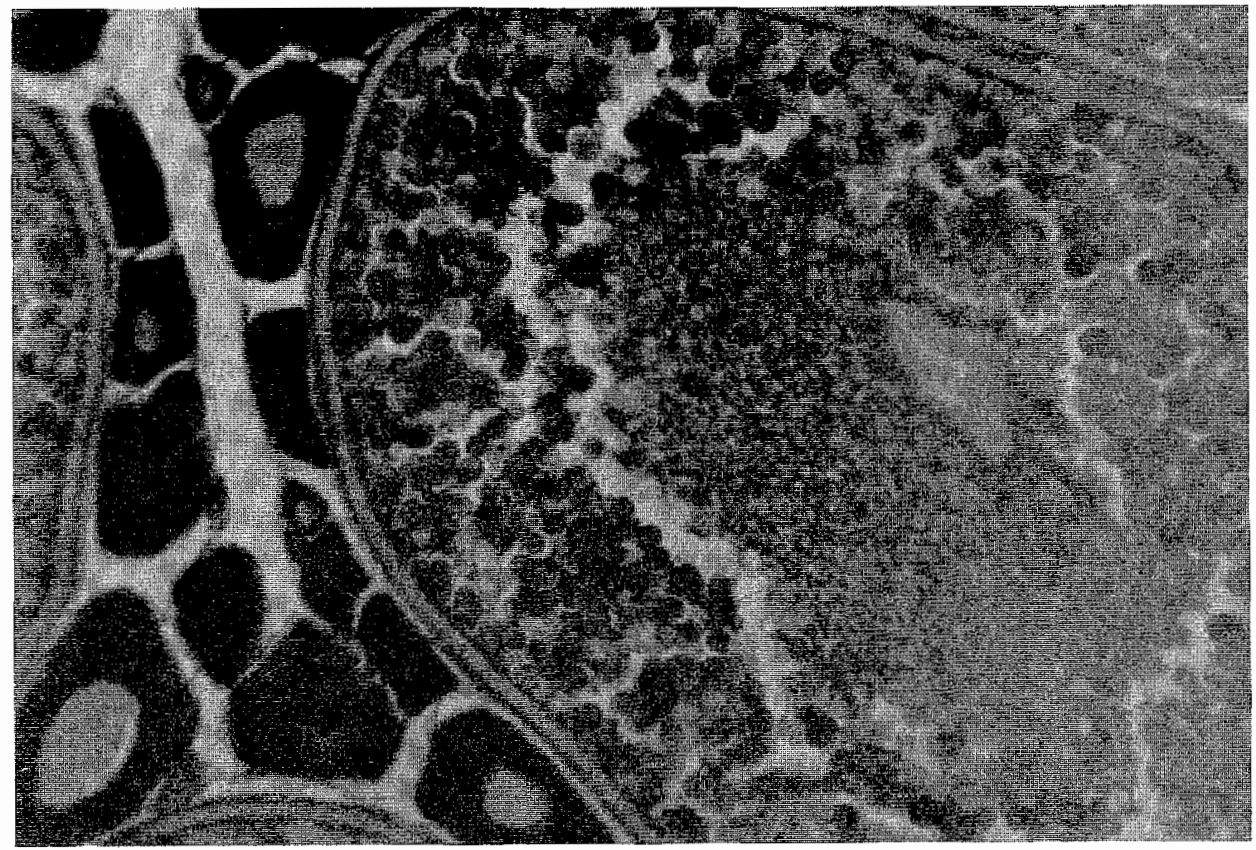

Phot. 1. Stage IV of maturity of bream female ovary in Ślesińskie Lake

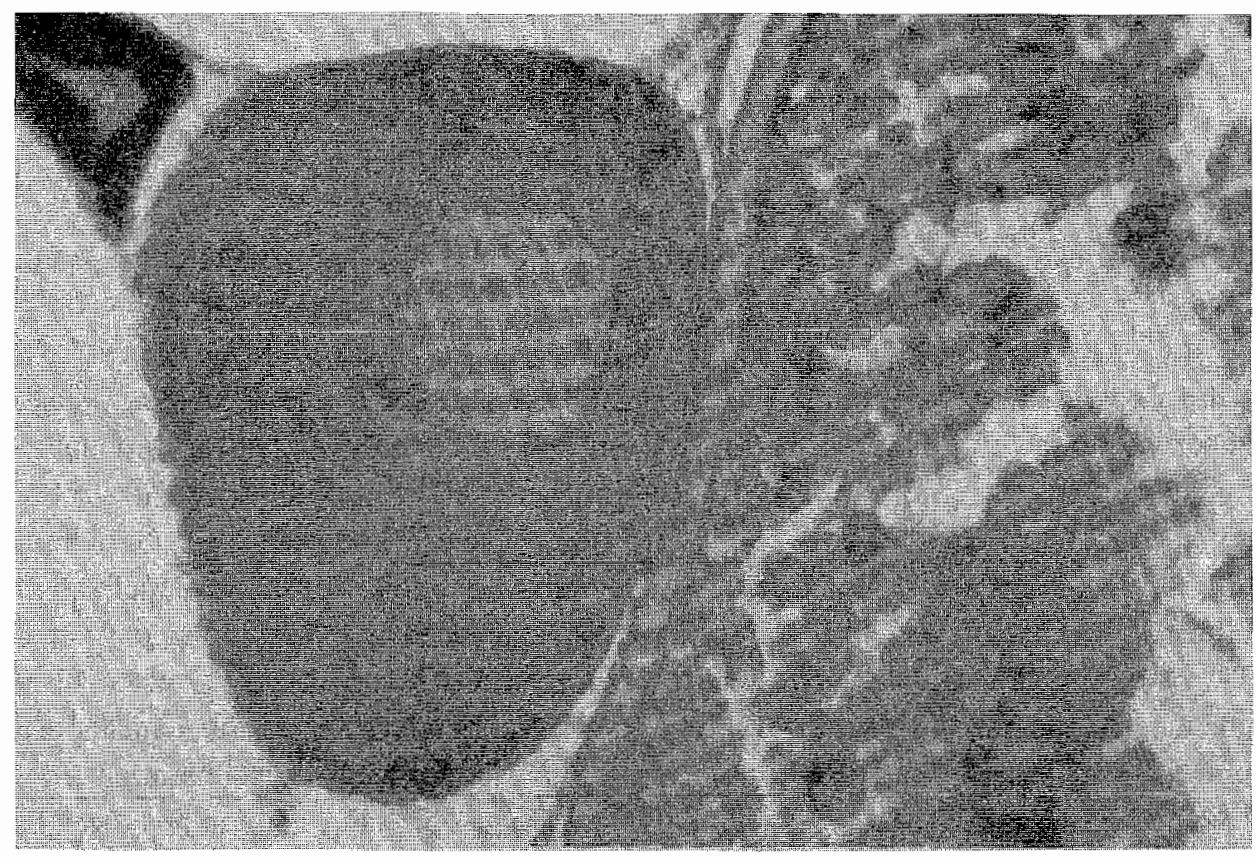

Phot. 2. Oocyte of bream female ovary at the beginning of vacuolization period in Ślesiniskie Lake 
Percentage of the oocytes of proto- and trophoplasmatic growth in the ovaries and individual data on bream females in Gosławskie Lake

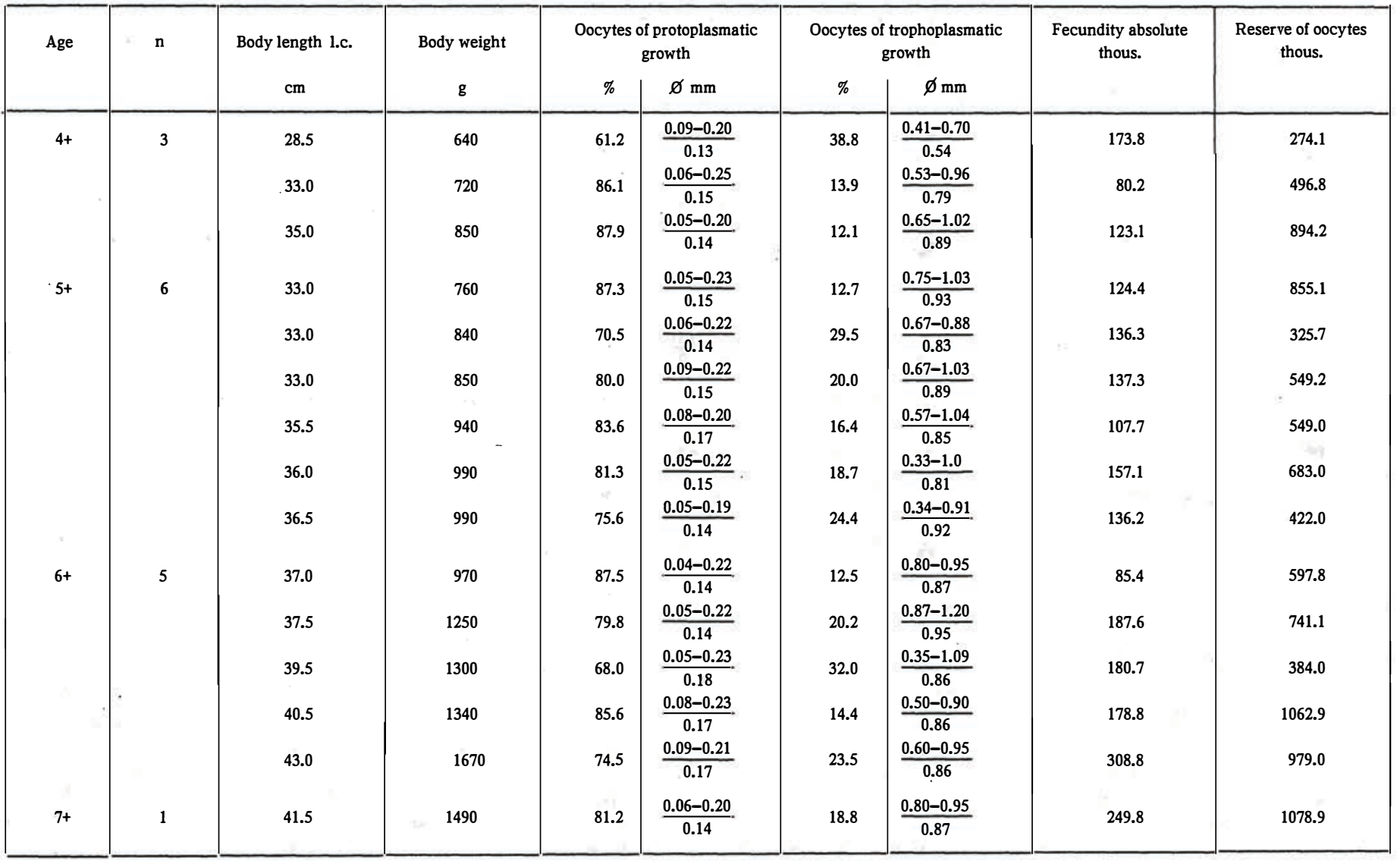

Total 15 
Table 2

Percentage of the oocytes of proto- and trophoplasmatic growth in the ovaries and individual data on bream females in Siesińskie Lake

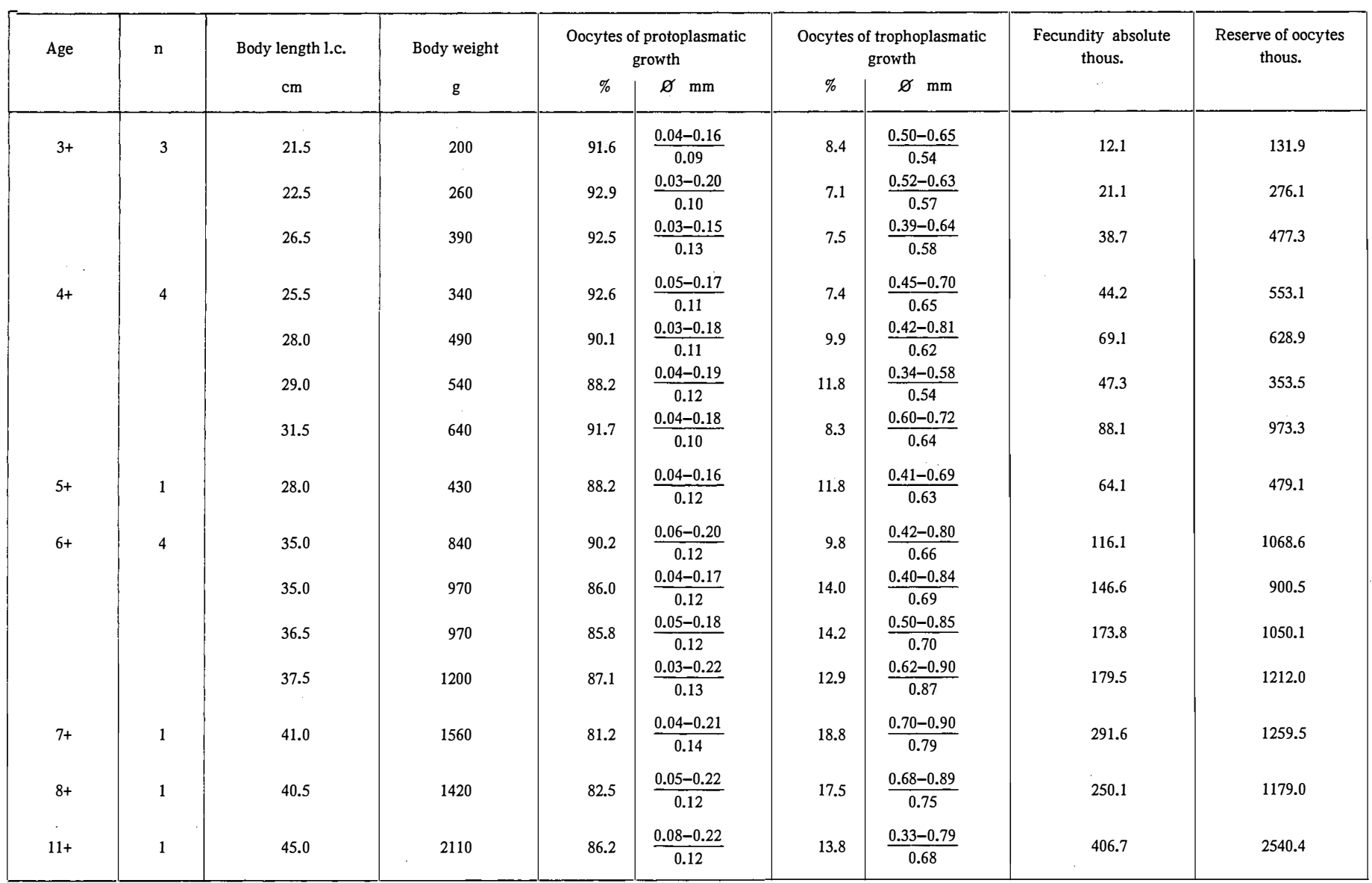

Total 15 
Reserve of the oocytes in the ovaries and absolute fecundity of bream females from Lake Gosławskie (G) and Lake Ślesińskie (Ś)

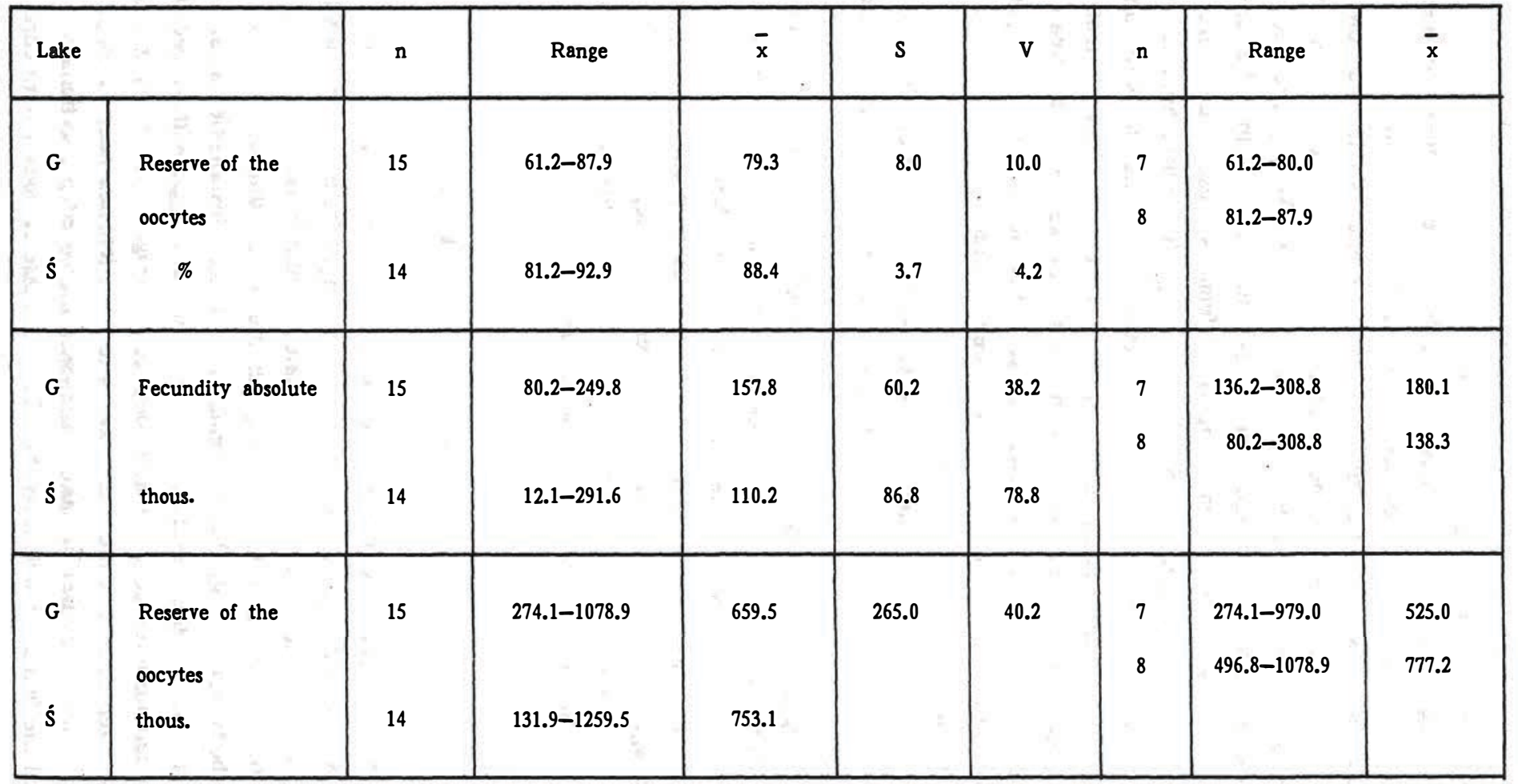


were 3-8 years old. One female was 11 years old. Their body length ranged from 21.5 to $41.0(45.0) \mathrm{cm}$ and weight from 200 to $1560(2110) \mathrm{g}$.

As regards percentages of oocytes in the ovaries of bream females it was found that percentage of the oocytes of protoplasmatic growth in females from Lake Gosławskie was more differentiated $(\mathrm{V}=10.0)$, and its value was lower $(61.2-87.9 \%$, $\overline{\mathrm{x}}=79.3 \%$ ) than the same percentage in the ovaries from bream females in Lake Ślesińskie $(V=4.2,81.2-92.9 \%, \bar{x}=88.4 \%)$, (Tab. 3). Eight females from Lake Gosławskie had the percentage of protoplasmatic oocytes within the range observed in Lake Ślesińskie. In the remaining seven females these values were lower. These females were characterized by higher average fecundity, butlower oocyte reserve (Tab. 3). In natural conditions higher fecundity is related to more numerous reserve oocytes of protoplasmatic growth in the ovaries, and their utilization during the vitellogenesis of about 14.5 to $19.6 \%$ (Kopiejewska 1993). In bream females from Lake Gosławskie which had lower percentage of the oocytes of protoplasmatic growth more eggs matured than could have been covered by the oocytes reserve, so this reserve was used in up to $32-38.8 \%$ (Tab. 1).

Bream females from Lake Gosławskie were characterized by higher diameter of oocytes of proto- and trophoplasmatic growth than the females from Lake Ślesińskie. From among the 15 examined females from Lake Gosławskie seven average diameter of protoplasmatic oocytes within the range $0.13-0.14 \mathrm{~mm}$, and the other had bigger diameter. In Lake Ślesińskie diameter of protoplasmatic oocytes was $0.13-0.14 \mathrm{~mm}$ in three females only, while the others (12) had these diameter within the range 0.09-0.12 mm. In Lake Gosławskie all females with the exeption of the smallest one (aged 4 years) had average diameter of trophoplasmatic oocytes greater than $0.70 \mathrm{~mm}$. In Lake Ślesińskie on three females were characterized by a similar value, in the other females these oocytes were smaller.

\section{ABSOLUTE FECUNDITY}

Absolute fecundity of bream population in Lake Gosławskie ranged from 71.2 to 308.8 thousand eggs. In Lake Ślesińskie it ranged from 12.1 to 406.8 thousand eggs. Absolute fecundity of the females related to individual characters was different in the two lakes (Fig. 3, 4, 5). As regards the relationship between absolute fecundity and body weight (Fig. 3) bream females from Lake Gosławskie had absolute fecundity lower than in Lake Ślesinskie by 20-30 thousand eggs. With respect to the relation between absolute fecundity and body length (Fig. 4) fecundity in Lake Gosławskie was lower than in Lake Ślesinskie when the females became longer than $32 \mathrm{~cm}$. Fecundity of females in Lake Gosławskie increased proportionally to body length. Until the females reached $38 \mathrm{~cm}$ a $2 \mathrm{~cm}$ increase of body length corresponded to an 


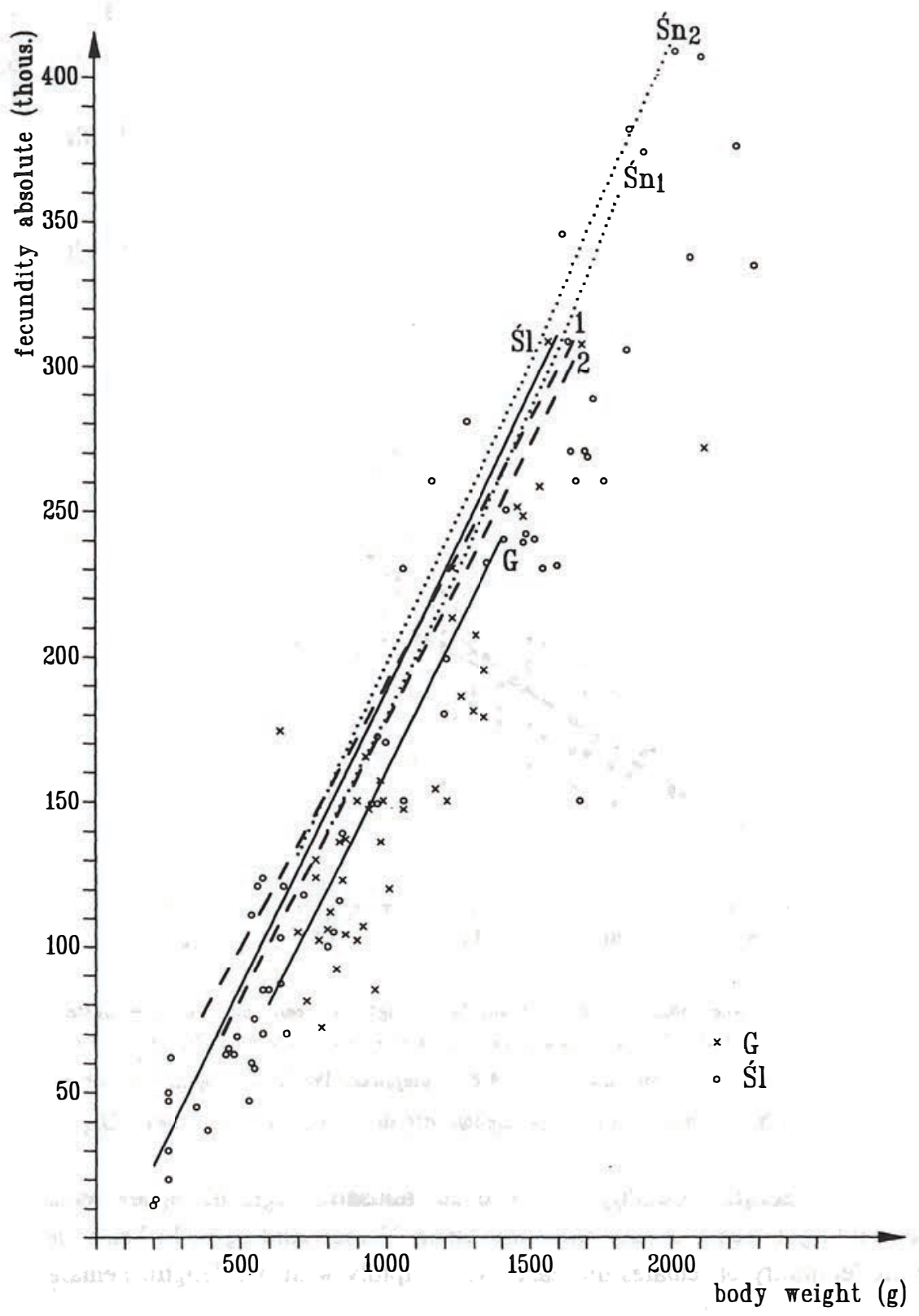

Fig. 3. Relationship between absolute fecundity and body weight of bream females: $G$ - Gosławskie Lake

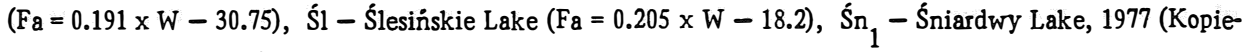
jewska 1987), $\dot{S}_{2}$ - Śniardwy Lake, 1978 (Kopiejewska 1987), 1 - population with average rate of growth (Brylińska 1971), 2- population with slow rate of growth (Bryliniska 1971) 


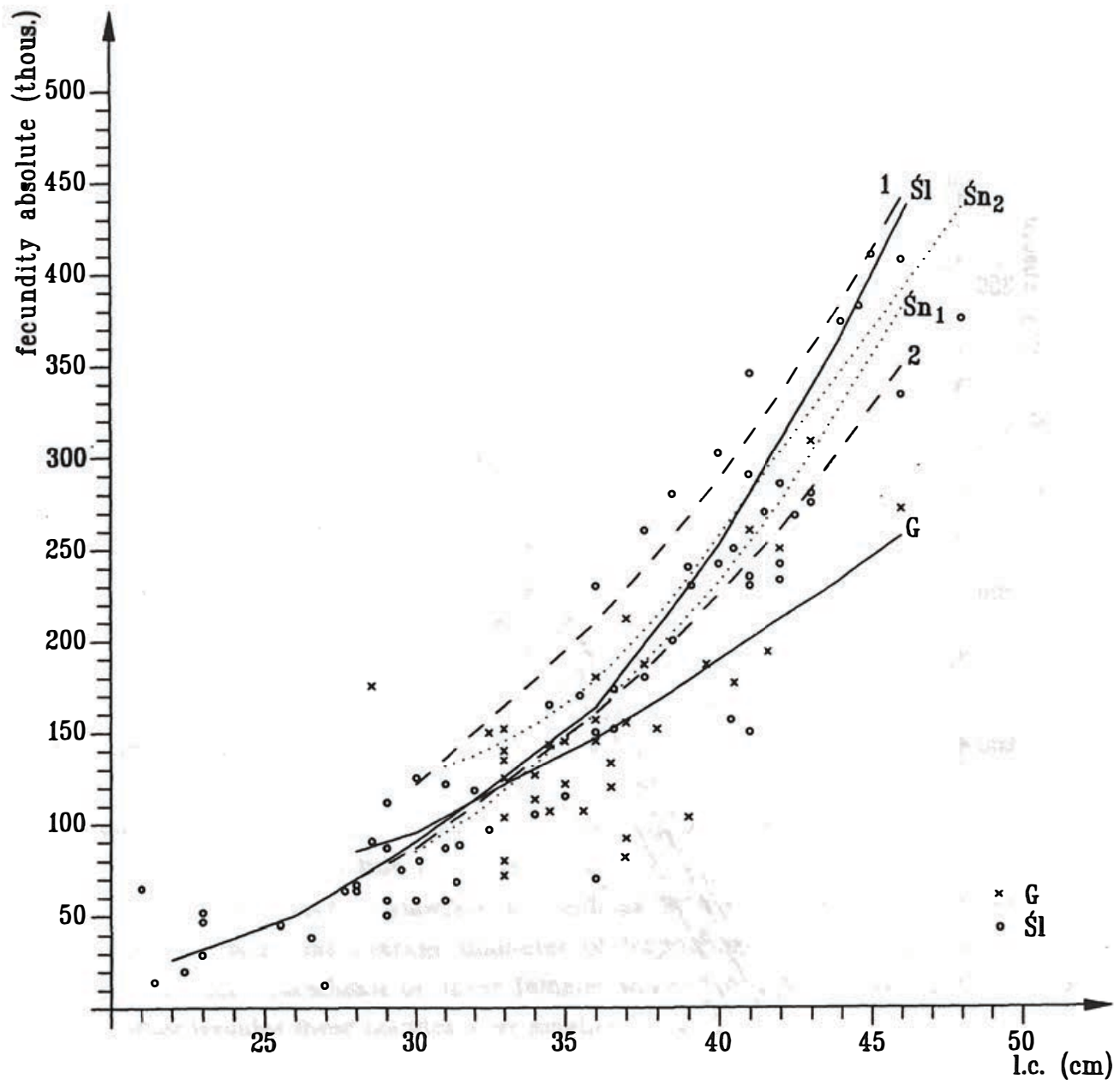

Fig. 4. Relationship between absolute fecundity and body length of bream females: $\mathrm{G}$ - Gosławskie Lake

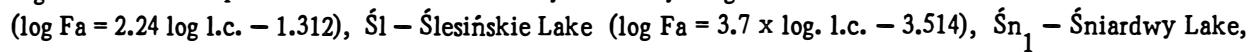
1977 (Kopiejewska 1987), $\dot{S}_{2}$ - Śniardwy Lake, 1978 (Kopiejewska 1987), 1 - population with average rate of growth (Bryliniska 1971), 2 - population with slow rate growth (Brylińska 1971)

increase of absolute fecundity by 16 to 20 thousand eggs. In bigger females the corresponding increase of fecundity was 20 to 24 thousand eggs. In Lake Ślesińskie absolute fecundity of females increased very rapidly with fish length. Females about $32 \mathrm{~cm}$ long had the same fecundity in both lakes i.e. about 110 thousand eggs, but females $10 \mathrm{~cm}$ longer had much higher absolute fecundity in Lake Ślesińskie, the difference being about 100 thousand eggs. At body length of $46 \mathrm{~cm}$ bream females in Lake Gosławskie by about 170 thousand eggs. A different picture was obtained when absolute fecundity was related to female age. Females from Lake Gosławskie 


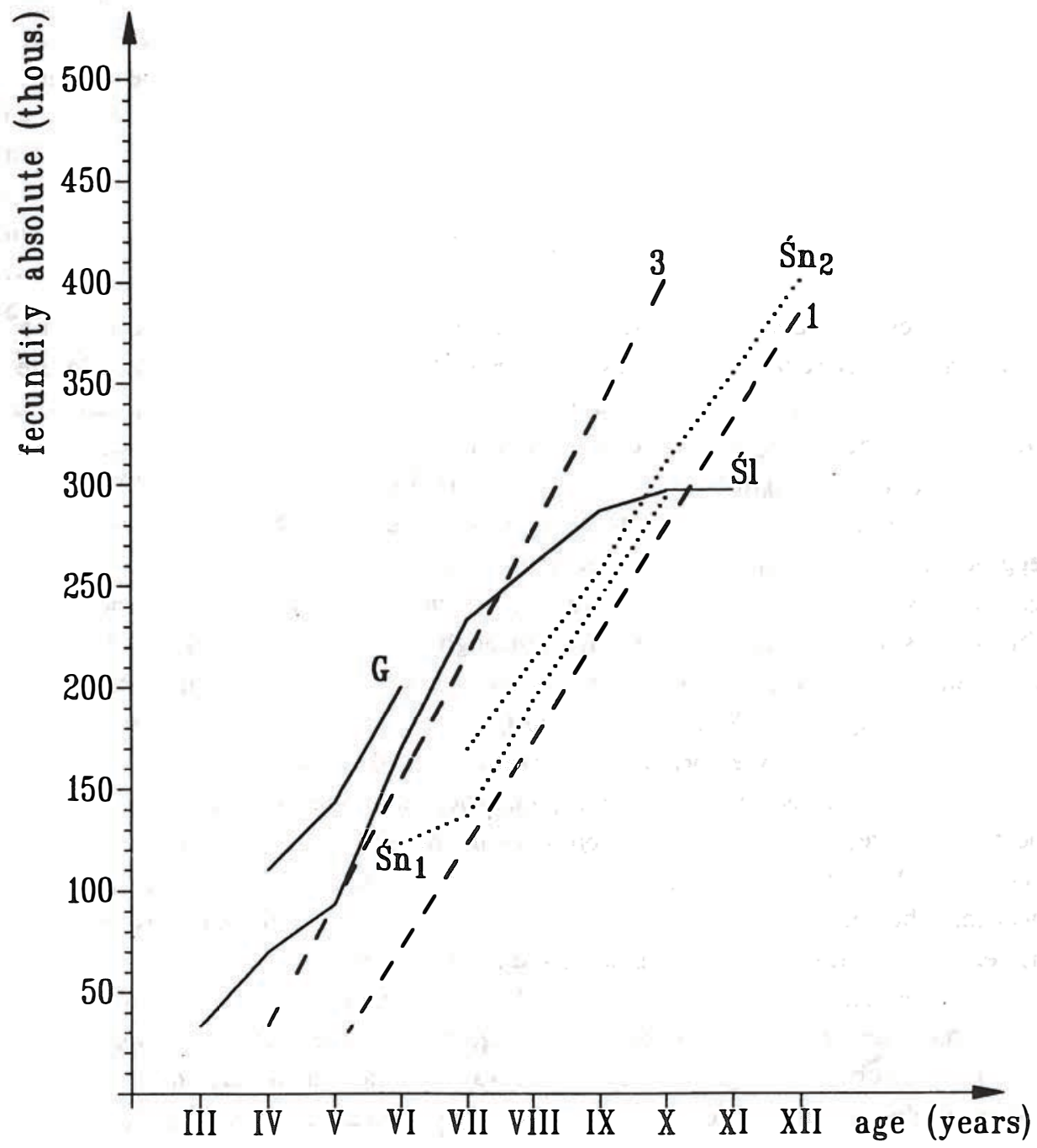

Fig. 5. Average absolute fecundity in age groups of bream females: G - Gosławskie Lake, Śl - Ślesińskie Lake, $\delta_{1}$ - Śniardwy Lake, 1977 (Kopiejewska 1987), $\delta_{n_{2}}$ - Śniardwy Lake, 1978 (Kopiejewska 1987), 1 - population with average rate of growth (Brylińska 1971), 3-population with rapid rate of growth (Brylińska 1971)

were characterized by higher absolute fecundity when particular age classes were taken into account (Fig. 5). Four, five and six years old females from Lake Gosławskie were characterized by higher average fecundity than the females of the same age in Lake Ślesińskie, the difference being some 30 to 50 thousand eggs. Increments of average fecundity in females of the same age were, however, greater in females from Lake Ślesińskie. 
The above results suggest that bream females in Lake Gosławskie were bigger and had higher absolute fecundity than females of the same age in Lake Slesińskie. Changes of absolute fecundity in relation do body weight and age were slower in Lake Gosławskie than in Lake Ślesińskie.

\section{DISCUSSION}

The species Abramis brama (L.) is regarded as one of the few characterized by different type of reproduction (Koshelev 1965). In thermally polluted lakes located within the geographic range of Abramis brama (L.) one batch spawning can occur in some fish belonging to the population with multi-batch type of spawning (Statova 1973), or there might be a trend for multi-batch spawning (Lukshene 1978).

Asynchronic development of the oocytes is connected with the formation of two egg portions in the ovaries. This phenomenon was observed in bream from Kaczurgański Reservoir of a Moldavian power plant (Statova 1973). The second portion of the oocytes wasestablished in the ovaries through vacuolization processes which took place already by the end of September, when the oocytes from the first portion had entered the stage of vitellogenesis. Prior to spawning, when vitellogenesis approached its end in the first oocyte portion, vacuolization was almost completed in the second oocyte portion, or else vitellogenesis began. When the females spawned the first egg portion, oocytes of the second portion were in the end phase of vitellogenesis, and oocytes in the initial stage of vacuolization appeared among oocytes of protoplasmatic growth. When the second portion of eggs was spawned, the ovaries were classified as being in VI-III stage of development, and then in stage III.

In a reservoir of a Lithuanian power plant (Lukshene 1978) most bream females were characterized by one-portion spawning, but in about $26 \%$ there was a trend for multi-batch spawning. This tendency was reflected in the fact that ovaries of spent females contained oocytes in the final stage of vacuolization and initial stage of vitellogenesis. This oocytes, however, did not attain maturity but were resorbed.

In south areas of the distribution of bream with one batch spawning, in the delta of River Terek (Shikhshabekov 1972) characterized by natural temperatures, there were bream stocks in which some females had oocytes in course of vacuolization even though the females had already spawned. These oocytes did not attain sexual maturity during the reproductive season and were resorbed.

Similar responces to increased water temperature were found in the case of roach females in Moszkowicki Reservoir of Konakowska power plant (Efimova 1977).

Observatins on the ovaries of bream females in lakes Gosławskie and Slesińskie (Phot. 1, 2) as well as the data from the literature suggest that spawning in lakes 
Gosławskie and Ślesińskie was one-portion, but about $25-26 \%$ of the females showed a tendency to multi-portion spawning. The ovaries of the latter females contained oocytes in final stage of vitellogenesis as well as oucytes in the initial stage of vacuolization. The latter oocytes did not attain sexulal maturity in the current reproductive season. In Lake Gosławskie bream females after 1970 spawned in March-April (personal communiaction of an employee of the fish farm. Samples were collected in mid-February and the begining of March). In 1966-1969 bream spawned in the two lakes in April-May-June (Wilkońska and Żuromska 1977 a). In natural conditions of Polish lakes bream spawns in May-June (Sych 1955, Pęczalska 1963, Brylińska and Długosz 1970, Kopiejewska 1989).

According to Oven (1976) potential fecundity i.e. the reserve of reproductive cells is of adaptable character when viewed as a reserve of reproductive cells ensuring reproduction in the given season and not as a reserve for future years.

The reserve of oocytes of protoplasmatic growth in the ovaries of bream females from two lakes: Kortowskie and Blanki (Kopiejewska 1993) ranged from 507.3 to 5806.3 thosand (8996.3 thousand), from which 20.8-321.3 thousand eggs were spawned, these being 1.5-14.5\% of the oocytes reserve. Proportions of maturing oocytes in the ovaries of brea females were characterized by low variability $(\mathrm{V}=$ = 2.4-5.5), (Kopiejewska 1993), suggesting that these proportions were a functional property of the ovaries. In bream population from lakes Śniardwy, Kortowskie and Blanki the reserve of oocytes of protoplasmatic growth ranged from (78.9) 80.4-98.5\% (Kopiejewska 1989, Kopiejewska 1993). Data characterizing functioning of ovaries in bream females from Lake Ślesińskie (81.2-92.9\%, V =4.2) were within the range of these values, but data from Lake Gosławskie were not within this range (61.2$-87.9 \%, \mathrm{~V}=10.0$ ). Hence, it may be stated that functional changes took place in the ovaries of some females from Lake Gosławskie under the effect of environmental conditions. In females from Lake Gosławskie percentage of oocytes of trophoplasmatic growth in relation to percentage of oocytes of protoplasmatic growth was lower than in other cases, this being especially noticeable in the case of females with low percentage of protoplasmatic oocytes in the ovaries. In these females there were 1.6-7.3 times more trophoplasmatic oocytes than protoplasmatic ones, and inthe females which had less protoplasmatic oocytes the numbers of trophoplasmatic oocytes was only 1.6-4.0 times higher. In Lake Ślesińskie percentage of oocytes of protoplasmatic growth was than the percentage of trophoplasmatic ones (fecundity) 4.3-13.1 times, while in natural conditions of Lake Kortowskie it was 6.4-27.6 higher (51.6 and 65.7), in Lake Blanki 8.4-39.0 higher (Kopiejewska 1993), and in Lake Śniardwy (3.7) 4.1-28.4 (Kopiejewska 1989). Bream females in Lake Gosławskie compared to the populations in lakes Kortowskie, Blanki and Ślesinskie were characterized by low number of oocytes of protoplasmatic growth (Tab. 4). Notwithstanding this, large number of eggs matured in the ovaries of these females (Tab. 4). This resul- 
Reserve of the oocytes in the ovaries and absolute fecundity of bream females from lakes: Gosławskie (G), Ślesiñskie (S), Kortowskie (K), Blanki (B)

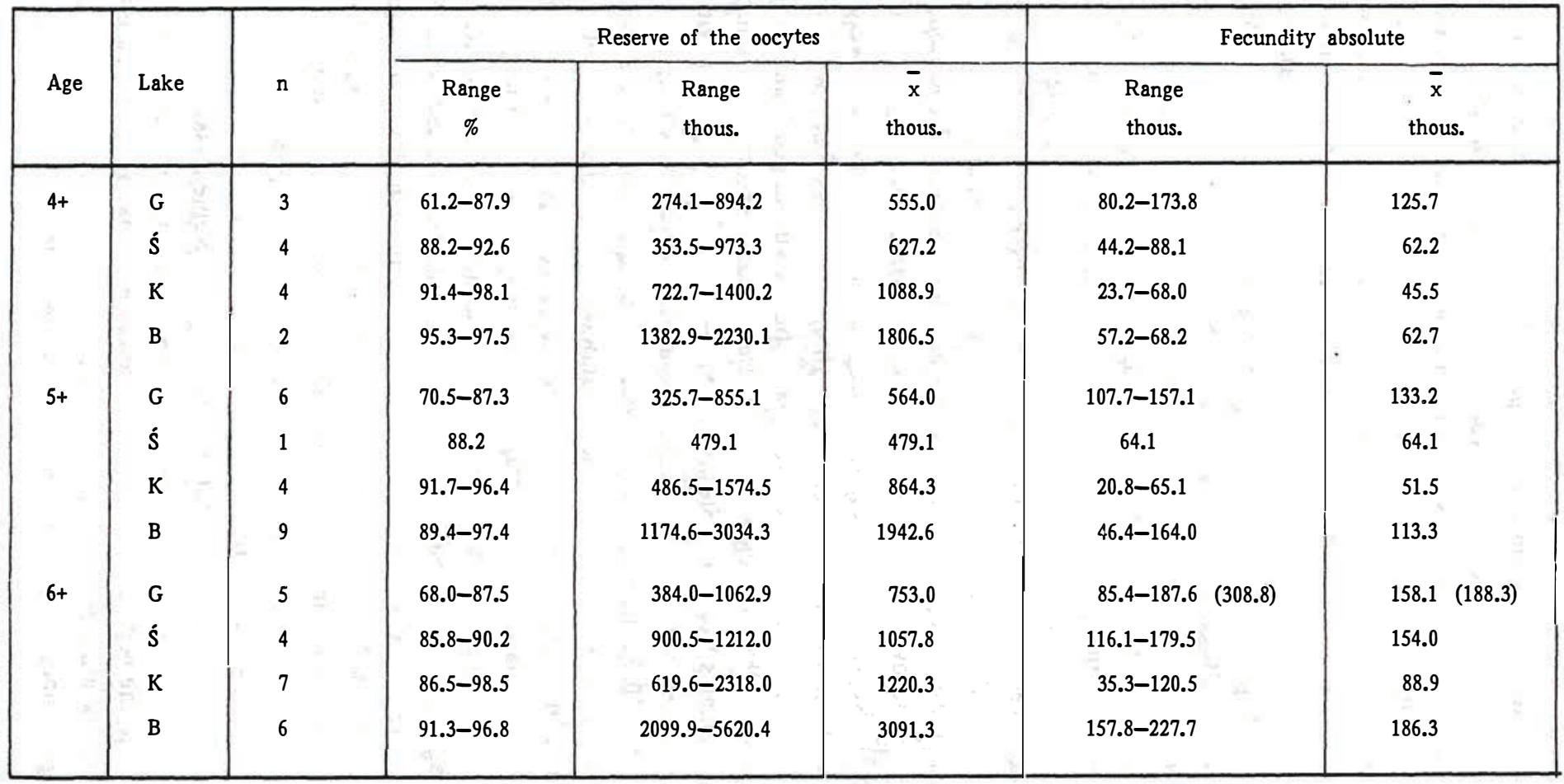


ted in considerable use of oocyte reserve in the ovaries. It can be concluded that in the conditions of Lake Gosławskie endo- and exogenesis took place in more oocytes than the number of oocytes entering in previtellogenetic period. i.e. the balance between vegetative oocyte development and premeiotic genertive phase was disturbed.

Lukshene $(1983,1986)$ stated that diameter of bream oocytes in the case of increased water temperature decreased as the females grew older. Oocyte diameter in bream females from Lake Gosławskie (more thermally polluted than Lake Slesinskie) was bigger than in Lake Slesińskie. It is possible that this was a population property. It is generally known that egg size depends on female size (Kazanski 1975) and females in Lake Gosławskie were bigger than in Lake Ślesinskie.

It was found that individual absolute fecundity of bream females in thermally polluted lakes was lower than in natural conditions (Lukshene 1983, Statova 1973), and that fecundity decreased with increasing pollution (Lukshene 1983).

Fecundity of bream females from lakes Gosławskie and Ślesinskie was compared to that in 15 Polish lakes (Brylinska 1971) and in Lake Śniardwy which had optimal conditions for this species (Kopiejewska 1987), (Fig. 3, 4, 5).

Absolute fecundity of bream females in Lake Slesinskie when related to body weight was very similar to that observed in Lake Sniardwy in the year when the females were characterized by lower condition, as well as to that calculated for 7 bream populations of moderate growth (Fig. 3). Bream females in Lake Gosławskie had lower fecundity than bream females of the same body weight in Lake Sniardwy. It was also lower than average fecundity calculated for bream populations characterized by slow growth. Considering the relation between absolute fecundity and body length (Fig. 4) fecundity of bream females from Lake Ślesinskie was lower than average fecundity of females in bream population of moderate growth, but was on the same level as fecundity of bream females from Lake Śniardwy. In Lake Slesińskie fecundity in. creased with body length more rapidly than in Lake Sniardwy. However, in Lake Gosławskie fecundity increased with body length slower than in Lake Sniardwy. Bream females in this lake were characterized by lower fecundity than in Lake Sniardwy and lower than in bream populations of slow growth. Only small females, about $34 \mathrm{~cm}$ in length, had fecundity similar to fecundity in Lake Śniardwy.

Bream females aged 8 years in Lake Šlesinskie had the same fecundity as 9 years old females in Lake Śniardwy, while those aged 9 years had similar fecundity as those 10 years old in Lake Śniardwy (Fig. 5). Ten and eleven years old females in Lake Slesinskie had fecundity lower than females of the same age in Lake Śniardwy. A decrease of fecundity increments in bream females from Lake Ślesińskie took place since the age of six years. Population in Lake Slesińskie was characterized by higher fecundity of younger females than of older ones compa- red to the populations in natural conditions. Three and four years old females had higher fecundity than the 
average one calculated for three bream populations with rapid growth, while five, six and seven years old females had the fecundity on the level of average fecundity of the population with rapid growth, and eight, nine and ten years old females had the fecundity within the range of average fecundities in the populations of rapid and moderate growth. On the other hand fecundity of bream females in Lake Gosławskie was higher than average fecundity of bream females in a population with rapid growth (Fig. 5). Females aged five, six years had the fecundity at the level of fecundity observed for seven, eight years old females in Lake Śniardwy.

The above data suggest that as regards the dependence of fecundity on body size, bream population in Lake Ślesinskie had the characteristics of the populations of moderate growth in natural conditions. Increased water temperatures in this lake induced more intensive egg development in three-seven-eight years old females than in the case of moderatly growing populations of this species. Number of eggs developing in the ovaries of these females was the same as in rapidly growing bream populations in natural conditions. Bream population in Lake Gosławskie had the characteristics of a slowly growing population in natural conditions when consideration was given to the dependence of fecundity on fish size, and of rapidly growing populations when attention was paid to the dependence of fecundity on fish age. Significant increase of temperature in Lake Gosławskie resulted in an even more intensive egg development in the ovaries of young bream females during reproduction, so that they passed from the population of slow growth to that of more intensive growth than in the populations of rapid growth.

\section{CONCLUSIONS}

1. In the conditions of lakes Gosławskie and Ślesinskie, which are thermally polluted by "Konin" and "Pątnő" power plants, bream females have single portion spawning. In about $25-26 \%$ of the females there is a tendency for multi-batch spawning. The ovaries of the latter females contain oocytes in the final stage of vitellogenesis (1st portion) as well as oocytes in the initial stage of vacuolization (2nd portion). The degree of development of this second egg batch suggests that they will not attain sexual maturity in the current reproductive season.

2. From 7.1 to $18.8 \%$ of the oocytes attained maturity in the annual cycle of ovary development in the case of females from Lake Ślesinskie. These values are within the limits noted for natural lakes. As regards bream females from Lake Gosławskie, $12.1-38.8 \%$ of the oocytes attained maturity in the annual cycle i.e. more than the upper limit observed in natural lakes. In about $46.6 \%$ females from Lake Gosławskie more oocytes mature in the ovaries than in natural conditions, $20.0-38.8 \%$. This causes depletion of the reserve of oocytes of protoplasmatic growth. Considerable 
heating of Lake Gosławskie resulted in some disturbances of the balance between vegetative and generative premeiotic phase of oocyte development (endo- and exogenic vitellogenesis takes place in more oocytes than the number of oocytes entering the previtellogenetic phase).

3. Lake Ślesinnskie receives periodic discharge of heated effluents from May till November. Fecundity of bream females in this lake amounts to from 12.1 to 406.8 thousand eggs at body length $21.0-48.0 \mathrm{~cm}$ and weight $200-2290 \mathrm{~g}$, aged 3-12 years. The relationship between fecundity and body weight and length is the same as in natural bream populations characterized by moderate growth. Heating of this lake intensified egg maturation in the reproductive cycle of younger females, aged three- seven years, so that it became similar to that noted in rapidly growing populations.

4. Lake Gosławskie is heated throughout the and its temperatures differ considerably from those noted in natural lakes. Fecundity of bream females in this lake ranged from 71.2 to 308.8 thousand eggs at body length $28.5-46.0 \mathrm{~cm}$ and weight 640-2110 g, the females being 4-7 years old. As regards the relationship between fecundity and body weight and length it was similar as in natural populations characterized by slow growth. Considerable heating of this lake intensifield egg maturation in females ovaries during the reproductive period, so that it became as in the rapidly growing populations.

\section{REFERENCES}

Brylin̊ska Mo, 1971: Czynniki regulujące indywidualną płodność absolutną oraz płodnoşć absolutną populacji leszcza (Abramis brama). [Factors regulating individual absolute fecundity in bream (Abramis brama) populations], Zesz. nauk WSR Olszt., C-2:1-104 (in Polish).

Brylinoska M., M. Dlugoes, 1970: Rozwój jajnika leszcza (Abramis brama L.) w cyklu rocznym. [Development of bream (Abramis brama L.) ovaries in the annual cycle]. Rocz. Nauk Rol. 92-H-1:7-25. (in Polish).

Chmielewski H., 1985: Zmiany w tempie wzrostu populacji płoci, Rutilus rutilus (L.), w podgrzewanych jeziorach Koniniskich. [Changes of the rate of growth in roach (Rutilus rutilus) population in heated Konin lakes]. M.Sc. Thesis, Inland Fisheries Institue, Olsztyn: 1-18. (in Polish).

Ciepielewaki W., 1977: Wzrost sandacza (Stizostedion lucioperca L.) w podgrzanym Jeziorze Licheńskim. [Growth of pikeperch (Stizostedion lucioperca L.) in heated Licheńskie Lake]. Rocz. Nauk roln. 97-H-4:7-16. (in Polish).

Długosz M., 1983 a: Rozwój gonad płoci (Rutilus rutilus L.) w podgrzewanych wodach Jeziora Gosławskiego. [Development of roach (Rutilus rutilus L.) gonads in heated Gosławskie Lake]. Rocz. Nauk roln. 100-H-1:73-90. (in Polish).

Diugosz M., 1983 b: Histologiczny obraz rozwoju jajnika okonia (Perca fluviatilis L.) w podgrzewanych wodach Jeziora Gosławskiego. [Histological picture of the development of perch (Perca fluviatilis L.) ovaries in heated Gosławskie Lake]. Rocz. Nauk roln. 100-H-1:57-72. (in Polish).

Diugase M., 1983 c: Obraz histologiczny gonad sandacza (Stizostedion lucioperca L.) z wód podgrzewanych Jeziora Gosławskiego. [Histological picture of pikeperch (Stizostedion lucioperca L.) gonads in heated Gosławskie Lake]. Rocz. Nauk roln. 100-H-2:29-43. (in Polish). 
Diugos Mog 1986: Owogeneza i cykl rocznego rozwoju gonad wybranych gatunków ryb w zbiornikach o odmiennych warunkach termicznych. [Oogenesis and annual cycle of gonad development in selected fish species from waters of different thermal conditions]. Acta Acad. Agricult. Techn. Olst. Protectio Aquarum et Piscatoria, 14-B:1-69. (in Polish).

Bfimova $\mathbb{T}_{\text {。A }}$ o, 1977: Vlijanie sbrosnykh teplykh vod Konakovskoj GRES na polovye cikly ryb Ivankovskogo vodokhranilishha。 $T r$. vses. gidrobiol。 O-va, 21:63-82. (in Russian)。

Hililbricht-Mllkowska $\mathbb{A}_{0}, \mathbb{B}_{0}$ Zdanowski, 1988 a: Main changes in the Konin lake system (Poland) under the effect of heated-water discharge pollution and fishery. Ekol。 pol. 36-1-2:23-45.

Hillbricht-Mllsowalca $\mathbb{A}_{0}, \mathbb{B}_{0}$ Zdanowski, 1988 b: Changes in lake ecosystems connected with the power-generating industry (the outline of problem); the Konin Lakes (Poland) as the study sites. Ekol. pol. $36-1-2: 5-21$.

Jalkubowski $\mathbb{H}_{0,}$ Peaczals $\mathbb{T}_{\text {og }} \mathbb{K}_{0}$ Urbanowicz, 1979: Morfologia i biologia klenia Leuciscus cephalus $\left(L_{\circ}\right) z$ wód zrzutowych elektrowni w Koninie. [Morphology and biology of Leuciscus cephalus ( $\mathrm{L}_{0}$ ) in heated effluents from Konin power plant]. Rocz. Nauk rol. 99-H-3:151-178. (in Polish)。

$\mathbb{K}$ azañslai $\mathbb{B}_{\text {oj }}$ 1975: Zakomernosti gametogeneza i ekologicheskaja plastichnost razmnozhenija ryb. In: Ekologicheskaja plastichnost polovykh ciklov i razmnozhenija ryb. Leningrad: 1-168. (in Russian).

Kolsurewice $\mathbb{B}_{\text {og }}$ 1979: Spawning of fish and their embryonic and larval development. Pol. ecol. Stud. $5-3: 64-71$.

Ropiejewska Wo, 1987: Plodnošc samic leszcza (Abramis brama Lo) w jeziorze Śniardwy. [Fecundity of bream (Abramis brama Lo) females in Śniardwy Lake]. Acta Acad. Agricult. Techn. Olst. Protectio Aquarum et Piscatoria. 15:55-66. (in Polish).

IRopiejewsicat Wos 1989: A reserve of the oocytes of protoplasmatic growth in the ovaries of bream (Abramis brama Lo) females in Lake Sniardwy. Acta Ichth. et Pisc. XIX-2:117-129.

TCopiejewska Wo, 1993: Zapas oocytów protoplazmatycznego wzrostu w jajnikach samic populacji leszcza Abramis brama (L.) Jeziora Kortowskiego i jeziora Blanki. [Reserve of oocytes of protoplasmatic growth in the ovaries of bream Abramis brama $\left(\mathrm{L}_{0}\right)$ females from Lake Kortowskie and Lake Blanki]. Acta Ichth。 et Pisc. XXIII-2:19-32。 (in Polish).

Koshelev B.Vo, 1965: Zakonomernosti izmenenija polovykh ciklov u ryb. In: Teoreticheskie osnovy rybovodstva. Nauka (in Russian).

Lulksheme DIKo, 1978: Vozdejstvie termicheskogo rezhima vodoemaokhladitelja Litovskoj GRES na vosproizvodstro ryb (1. Osobennosti polovogo cikla leshha). Tr. Akad. nauk LSSR 4(84)-V:81-91.

Lulkshene D.Ko, 1983: Osobennosti vosproizvodstva ryb v vodokhranilishhe-okhladitele Litovskoj GRES. Avtoreferat. Moskva: 1-25.

Lulkshene $\mathbb{D}_{0} \mathbb{K}_{0,}$ 1986: Gametogenez i polovye cikly ryb. In: Bazovoe sostojanie populjacij i soobshhestv vodnykh zhivotnykh v ozere Drukshjaj. Vilnjus. "MOKSLAS": 129-135. (in Russian)。

Marcials $\mathbb{Z}_{\text {os }}$ 1977: Wpìyw podgrzania wody przez elektrownie cieplną na wzrost leszcza w jeziorach Koninskich. [The eiffect of heated water discharge from a power plant on growth of bream in Konin lakes]. Rocz. Nauk roln.97-H-4:17-43. (in Polish).

Oven Ios.s. 1976: Osobennosti oogeneza i kharakter neresta morskikh ryb. Kiev。 "Naukova dumka": 1-131.

Begczalska Ao, 1963: Z biologii rozrodu leszcza Zalewu Szczeciñskiego. [On the biology of reproduction of bream in Szczecin Firth]. Pol。Arch. Hydrob. XII-1:109-139. (in Polish)。

Salsum OF。 NaA Buckajas 1968: Opredelenie stadij zrelosti i izuchenie polovykh ciklov ryb. Minist. Rybr. Khoz。 SSSR. Murmansk。(in Russian)。

Statova MoPor 1973: Polovye sozrevanie, razmnozhenie i plodovitost. In: MoF. Jaroshenko (Edo) Kuchurganskij liman=okhladitel Moldavskoj GRES. Izdat. "Stunca" Kishynev。: 148-169.

Sych $\mathbb{R}_{0}$ 1955: Obserwacje nad rozrodem ryb w łasze Konfederackiej w šrodkowym biegu rzeki Wisły. [Observations on the fish reproduction from Konfederacka shallow in the middle course of Vistula River]. Rocz.Nauk Rol。69-B-4:527-546. (in Polish)。

Szczyglinista Aog 1980: Cechy merystyczne populacji ploci-Rutilus rutilus ( $\left.L_{0}\right)$ i okonia-Perca fluviatilis L. pochodzących ze zbiornika naturalnego oraz termicznie zanieczyszczanego. [Meristic parameters in roach, Rutilus rutilus $\left(\mathrm{L}_{0}\right)$ and perch, Perca fluviatilis $\mathrm{L}_{\text {., }}$ populations from natural and thermally polluted waters]. Zesz。 nauk. ART Olszt。10:263-278. (in Polish)。 


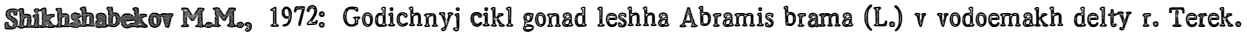
Vopr. Ikht. 12-1:193-197.

Willronsca Hos 1977: Wrost ploci (Rutilus rutilus Lo) w podgrzewanym Jeziorze Lichenskim. [Growth of roach (Rutilus rutilus L。) in heated Lichensskie Lake]. Rocz. Nauk roln.97-H-4:60-75. (in Polish)。

Wirnsoms $\mathbb{H}_{0} 1988$ a: The effect of heated-water discharge in the Konin Lakes (Poland) on their ichthyofauna. Ekol. pol. 36-1 - 2:145-163.

Winkenter Ho, $1988 \mathrm{~b}$ : The effect of the introduction of herbivorous fish in the heated Lake Gosiawskie (Poland) on the fry of local ichthyofauna. Ekol. pol. 36-1-2:275-281.

Wilp onstka $\mathbb{H}_{0}$ 1989: Wplyw wieloletniego ogrzewania na populacje naryblowe jezior Koninsskich. [The effect of long-term heating on fry communities in Konin lakes]. Rocz. Nauk roln. 102-H-2:83-95. (in Polish).

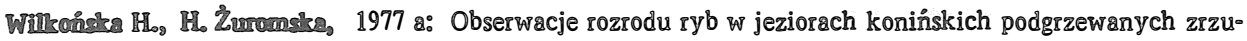
tami ciepłych wood $z$ elektrowni. [Observations on fish reproduction in Konin lakes heated with thermal effluents from a power plant]. Rocz. Nauk roln. 97-H-4:77-89. (in Polish).

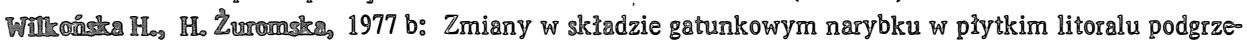
wanych jezior koniniskich. [Changes in species composition of fry in shallow littoral of heated Konin lakes]. Rocz. Nauk roln. 97-H-4:113-134。(in Polish).

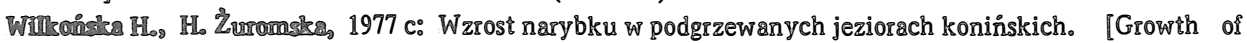
fish iry in heated Konin lakes]. Rocz. Nauk roln.97-H-4:91-111. (in Polish).

Will niñskich. [Changes in species composition of fish fry in heated Konin lakes]. Rocz. Nauk roln. 100-H$-2: 149-165$. (in Polish).

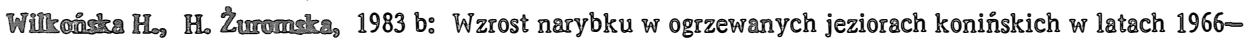
-1975. [Growth of fish fry in heated Konin lakes in 1966-1975]. Rocz. Nauk roln. 100-H-2:123-148. (in Polish).

Zdamowala Bos Ao Rorycka, 1976: Wpłyyw zrzutu wo̊d podgrzanych na stosunki termiczno-tlenowe i przeźroczystosic wody jezior koniniskich. [The effect of heated efiluent discharge on thermal and oxygen conditions and water transparency in Konin lakes]. Rocz. Nauk roln.97-H-3:141-164. (in Polish).

Zuromalka $\mathbb{H}_{0}$ 1977: Wrrost wzdregi (Scardinius erythrophthalmus (Lo) w jeziorze sztucznie podgrzewanym. (Growth of rudd [Scardinius erythrophthalmus $\left(\mathbb{L}_{0}\right)$ ) in artificially heated lake]. Rocz. Nauk roln. 97-H-4:135-151.(in Polish)。

Translated: Dr M. Bniniska

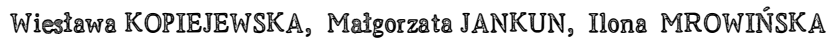

PLODNOS̊C I ZAPAS OOCYTÓW PROTOPLAZMATYCZNEGO WZROSTU W JAJNIKACH SAMIC LESZCZA ABRAMIS BRAMA (L) W DWÓCH ZBIORNIKACH JEZIOR KONIŃSKICH

\section{STRESZCZENIE}

Zbadano plodnos̊c i okres̊lono proporcje oocytơ w jajnikach samic leszcza Jeziora Goslawskiego i Je ziora \$llesin̊skiego. Jeziora te sa zanieczyszczane termicznie przez system chlodzenia elektrowni "Konin" i "Pątroow". Temperatura wody Jeziora Gosławskiego podwyższona jest w poro̊wnaniu z temperaturą wody s̊rodowiska naturalnego o $1.5-6^{\circ} \mathrm{C}$, Jeziora \$lesin̊skiego o $0.5-3.5^{\circ} \mathrm{C}$ w odpowiednich porach roku. Samice leszcza w tych jeziorach maja tarło jednomiotowe. U ok. $25 \%$ samic w obu jeziorach wystepuje tendencja do tarła porcyjnego. W cyklu rocznym rozwoju jajnikơw samic leszcza w Jeziorze \$lesiniskim dojrzew 7.1-18.8\% oocyto̊w, podobnie jak w warunkach naturalnych, u samic leszcza w Jeziorze Gosławskim dojrzewa od 12.1 do $38.8 \%$ oocytôw, u ok. $46 \%$ samic więcej niz w warunkach naturalnych. Podwyższona tempera- 
tura wody w Jeziorze S̊lesińskim spowodowała intensywniejsze dojrzewanie jaj w jajnikach młodych samic 3-7-letnich, z poziomu populacji średnio rosnących do poziomu populacji szybko rosnących. W Jeziorze Gosławskim wyższa temperatura wody jeszcze bardziej zintensyfikowała dojrzewanie jaj w jajnikach miodych samic 4-6-letnich, z poziomu populacji powoli rosnących do poziomu przekraczającego średni poziom populacji o szybkim wzroście.

Author's address:

Received: 1993.04 .13

dr Wiesława Kopiejewska

Katedra Zoologii,

dr Małgorzata Jankun-Woźnicka,

mgr Ilona Mrowińska-Dudkiewicz

Katedra Podstawowych Nauk Rybackich

Akademia Rolniczo-Techniczna

10-957 Olsztyn-Kortowo

Polska (Poland) 